\title{
Optimization of Methods and Systems for Strategic and Operational Management Accounting in Agricultural Enterprises
}

\author{
Lubov I. Ryzhova ${ }^{1}$, Lidiya V. Nikolaeva ${ }^{1}$, Nadezhda V. Kurochkina ${ }^{1}$ \& Marina E. Lebedeva ${ }^{1}$ \\ ${ }^{1}$ Mari State University, Yoshkar-Ola, Russia \\ Correspondence: Lidiya V. Nikolaeva, Mari State University, Lenin Sq., 1, Yoshkar-Ola, 424000, Russia.
}

Received: February 21, 2015 Accepted: March 15, 2015 Online Published: April 29, 2015

doi:10.5539/res.v7n8p119

URL: http://dx.doi.org/10.5539/res.v7n8p119

\begin{abstract}
The article focuses on the cost management accounting system as a basis for effective strategic and operational management and a guarantor for maximum profit. It examines various methods of cost management in agricultural holdings and enterprises. Characteristics of the methods are presented in the article. Such conditions for the use of methods as division of costs into variable and fixed, determination of main activities, continuous cost control, marketing forecasts, product competitiveness, the state of internal processes of the enterprise are considered. Direct costing, CVP-analysis and Standard Cost are examined in more detail. The calculation of the contribution margin from cattle breeding products and appropriate management document are presented. The article explores advantages and disadvantages of methods with appropriate recommendations for their use in agricultural enterprises. The calculation of the actual costs variances from standards is shown. Prerogative ways of improving the management accounting system in an unstable financial situation through the appropriate choice of methods and cost management system are defined.
\end{abstract}

Keywords: costs, cost management, management accounting, methods, accounting systems, agriculture, calculation

\section{Introduction}

Nowadays any commercial organization must have adequate information about business costs to increase profits that is why it should choose appropriate cost management methods to make strategic management decisions. In modern economic science there is a variety of methods and techniques which are applied to control costs. The choice of a method primarily depends on the aims the business sets and conditions for their application.

Such research methods as observation, comparison, methods of theoretical knowledge, analysis, abstraction, generalization, induction, modeling and system approach were used in the study.

\section{Results and Discussions}

Represented in Table 1, methods of cost management can be used both for strategic and operations management. They are quite diverse in content and differ in their objectives and characteristics; each method has drawbacks that limit its use and benefits.

Table 1. Characteristics and conditions for the use of methods

\begin{tabular}{|c|c|c|}
\hline Methods & Characteristics & Conditions for use \\
\hline Direct costing & $\begin{array}{l}\text { Overheads are not included in the cost of goods } \\
\text { (services), but in the accounts for the financial } \\
\text { reference period. }\end{array}$ & $\begin{array}{l}\text { Possibility to divide costs into variable } \\
\text { and fixed. }\end{array}$ \\
\hline Standard costing & $\begin{array}{l}\text { Each type of costs (material, labor) has } \\
\text { standards per unit of goods (services). Standard } \\
\text { costs and variances are considered separately. }\end{array}$ & $\begin{array}{l}\text { Possibility to use standard system, } \\
\text { calculate and analyze variances. }\end{array}$ \\
\hline $\begin{array}{l}\text { Activity based } \\
\text { costing } \\
(\mathrm{ABC})\end{array}$ & $\begin{array}{l}\text { It determines the relationship between activity, } \\
\text { product and cost and defines the cost of each } \\
\text { activity. }\end{array}$ & $\begin{array}{l}\text { Determination of main activities, } \\
\text { expansion of the existing accounting } \\
\text { system, personnel training. }\end{array}$ \\
\hline
\end{tabular}


Target costing Target cost is established on the basis of a selling price of goods (services) and the desired profit which is provided by efforts of all divisions of the company. It is a tool for strategic cost management.

Kaizen costing It aims at continuous improvement. The focus is on eliminating waste. It is mainly used in cost management and costs control.

CVP-analysis (cost volume profit analysis)

BSC (Balanced Scorecard)

Absorption-costi ng

Benchmarking

Cost

Cost-killing

Life Cycle

Costing (LCC)
The cost of a product includes all costs of a business.

It aims at calculating breakeven point and required number of units to achieve a target profit. Three main values are fixed costs, contribution per unit, required profit. The margin of safety is also calculated.

The main purpose is to provide all necessary information for making strategic management decisions.

It involves comparison of the cost management of the company with the cost management of a leading company in order to make the right management decisions in the area of business.

It aims at reducing business costs over a short period of time without any harm to the company. It is used for crisis management.

The method is used to determine the total cost of a certain product and compare it with the corresponding income. It is mainly used for the strategic cost management.
Close horizontal interaction between divisions of the company, implementation of continuous monitoring of the cost level, reliability of the market forecast.

Slight changes in production processes, which can lead to a significant result in future; involvement of all employees and all areas of the business in improving production and financial activities.

Sales price, fixed costs and variable costs are constant, actual fixed and variable costs correspond to planned ones.

Balanced Scorecard sets clear goals and objectives, as well as indicators of their achieving within the four main areas: finance, marketing, internal business processes, learning and growth.

The use of the most appropriate methods of overhead allocation to determine absorbed overhead costs which are included in the cost per unit.

Adequate information about business activities of the company and basic methods of achieving them.

Adequate information about business costs. Managers should aim at achieving cost reduction.

Reliable and detailed market research data; the identification of competitive products (services) of the company.

We will consider such methods as direct costing, CVP-analysis and Standard Cost in more detail.

Within the framework of management accounting there is total cost accounting and partial cost accounting. Total cost accounting should be applied when making long-term management decisions, but partial cost accounting is more effective in making immediate management decisions on control of costs, production output and its selling, establishing the lower limit price according to inflation, supply and demand. Partial cost accounting can be applied both to the whole company and to its divisions (Drury, 1998). While using partial cost accounting or direct costing, costs can be grouped according to the place of origin and centers of responsibility: groups, teams, farms. In this case, the places of origin and centers of responsibility keep records of variable costs. Fixed cost accounting is also carried out in the centers of responsibility. Such organization and model of applying cost accounting will allow to value the profitability of manufactured products, payback of the variable costs, final financial results for the whole business, to plan the volume of output taking into account available resources and production capabilities, to set standards for costs and find optimal selling prices (Ryzhova, 2009).

At the present time total cost accounting is used in agricultural organizations. This system is traditional and includes all the costs of goods produced. Total cost accounting is important for the business and financial performance, accrual of tax payments, but it does not provide all the information necessary for the effective cost 
management (Pizengolts, 2002). That is why, it is necessary to examine direct costing. In the context of direct costing, costs are divided into variable and fixed. The cost of a product is determined in portion of the variable costs. This method also includes the calculation of contribution margin and operating profit. To make these calculations, it is important to divide the costs properly into variable and fixed. The calculation of contribution margin gives an opportunity to make comparison of production efficiency of different kinds of agricultural products. Financial result that reflects a profit or a loss of a produced agricultural product is a good performance measurement. In order to make the right management decision at farm level, the measure of contribution margin is the most objective and simplest in calculations (Drury, 1998).

If we consider the agricultural enterprises of the Republic of Mari El in general, we will see that they produce various kinds of products, and the amount of fixed costs is common to all kinds. For this reason, the calculation of contribution margin will be more appropriate for enterprise cost accounting, because it determines the production efficiency of certain kinds of agricultural products of the company. We will consider partial cost accounting based on contribution margin of ZAO PP "Semenovskiy". Some general information on the enterprise is conditional. We can estimate production efficiency of certain kinds of products using the data in Table 2 (Ryzhova \& Nikolaeva, 2014). For example, milk production and sale of young cattle are more effective in cattle farming, the contribution margin of which is 4141.43 thousand roubles.

Table 2. The calculation of contribution margin in ZAO PP "Semenovskiy" for 2014, thousand roubles

\begin{tabular}{|c|c|c|c|c|c|}
\hline \multirow{2}{*}{ Items } & \multirow{2}{*}{$\begin{array}{l}\text { General } \\
\text { information }\end{array}$} & \multicolumn{2}{|c|}{ Kind of a product } & \multirow[b]{2}{*}{ young cattle } & \multirow{2}{*}{ Total } \\
\hline & & milk & meat & & \\
\hline 1. Cow population, heads & 145 & $\mathrm{x}$ & $\mathrm{x}$ & $\mathrm{x}$ & $\mathrm{x}$ \\
\hline 2. Young cattle population, heads & 180 & $\mathrm{x}$ & $\mathrm{x}$ & $\mathrm{x}$ & $\mathrm{x}$ \\
\hline 3. Bulls, heads & 19 & $\mathrm{x}$ & $\mathrm{x}$ & $\mathrm{x}$ & $\mathrm{x}$ \\
\hline 4. Milk produced, kg & 145967 & $\mathrm{x}$ & $\mathrm{x}$ & $\mathrm{x}$ & $\mathrm{x}$ \\
\hline 5. Milk yield per forage-fed cow, $\mathrm{kg} /$ heads & 1007 & $\mathrm{x}$ & $\mathrm{x}$ & $\mathrm{x}$ & $\mathrm{x}$ \\
\hline 6. Gain in weight, $\mathrm{h}$ & 377.09 & $\mathrm{x}$ & $\mathrm{x}$ & $\mathrm{x}$ & $\mathrm{x}$ \\
\hline 7. Average daily gain in weight, $g$ & 582 & $\mathrm{x}$ & $\mathrm{x}$ & $\mathrm{x}$ & $\mathrm{x}$ \\
\hline 8. Animal yield, heads & 127 & $\mathrm{x}$ & $\mathrm{x}$ & $\mathrm{x}$ & $\mathrm{x}$ \\
\hline 9. Annual cow disposal, \% & 15 & $\mathrm{x}$ & $\mathrm{x}$ & $\mathrm{x}$ & $\mathrm{x}$ \\
\hline 10. Milk produced, bottles & $\mathrm{x}$ & 237668 & $\mathrm{x}$ & $\mathrm{x}$ & $\mathrm{x}$ \\
\hline 11. Sold & $\mathrm{x}$ & $\begin{array}{l}237668 \\
\text { bottles }\end{array}$ & $2850 \mathrm{~kg}$ & 77 heads & $\mathrm{x}$ \\
\hline 12. Average selling price per unit. & $\mathrm{x}$ & 30.47 & 167.52 & $\begin{array}{l}169.87 \\
\text { roubles per kg }\end{array}$ & $\mathrm{x}$ \\
\hline 13. Sales proceeds, thousand roubles & $\mathrm{x}$ & 7241.1 & 477.4 & 3871.9 & 11590.4 \\
\hline \multicolumn{6}{|l|}{ 14. Variable costs, thousand roubles: } \\
\hline - Labour cost; & $\mathrm{x}$ & 456.51 & 37.02 & 187.16 & 680.69 \\
\hline - Biologies; & $\mathrm{x}$ & 1.80 & 0.15 & 0.63 & 2.58 \\
\hline - Zootechnical and veterinary care; & $\mathrm{x}$ & 18.41 & 1.47 & 6.54 & 26.42 \\
\hline - Milk; & $\mathrm{x}$ & 3114.56 & $\mathrm{x}$ & $\mathrm{x}$ & 3114.56 \\
\hline - Feed; & $\mathrm{x}$ & $\mathrm{x}$ & 275.39 & 2157.37 & 1332.76 \\
\hline - Raw materials and supplies; & $\mathrm{x}$ & 365.28 & 29.62 & 128.05 & 502.95 \\
\hline - Heat supply; & $\mathrm{x}$ & 20.99 & 1.70 & 7.36 & 30.05 \\
\hline - Electric power supply; & $\mathrm{x}$ & 87.09 & 7.06 & 30.52 & 154.72 \\
\hline - Bottles; & $\mathrm{x}$ & 414.64 & $\mathrm{x}$ & $\mathrm{x}$ & 414.64 \\
\hline - Other materials; & $\mathrm{x}$ & 15.41 & 1.23 & 5.40 & 22.04 \\
\hline
\end{tabular}


- Tractor fleet services;

$\begin{array}{lllll}\mathrm{x} & 18.75 & 1.52 & 6.71 & 26.98 \\ \mathrm{x} & 11.00 & 34.35 & 55.67 & 71.02 \\ \mathrm{x} & 4524.05 & 339.51 & 2585.41 & 7448.97 \\ \mathrm{x} & 2717.05 & 137.89 & 1286.49 & 4141.43 \\ \mathrm{x} & 11.43 & 48.38 & 10.69 & \mathrm{x}\end{array}$

- Other services.

Total variable costs, thousand roubles

15. Contribution margin, thousand roubles

48.38

10.69

645.72

- Manufacturing costs;

- Overheads;

- Selling costs

Total fixed costs, thousand roubles

18. Operating profit, thousand roubles

$\begin{array}{lllll}\mathrm{x} & \mathrm{x} & \mathrm{x} & \mathrm{x} & 645.72 \\ \mathrm{x} & \mathrm{x} & \mathrm{x} & \mathrm{x} & 1023.95 \\ \mathrm{x} & \mathrm{x} & \mathrm{x} & \mathrm{x} & 94.66 \\ \mathrm{x} & \mathrm{x} & \mathrm{x} & \mathrm{x} & 1764.33 \\ \mathrm{x} & \mathrm{x} & \mathrm{x} & \mathrm{x} & 2377.10\end{array}$

One of the main tools of making management decisions is cost volume profit analysis or CVP-analysis, the aim of which is to determine the breakeven point, which shows the sales volume that is required to cover total costs and reach a zero profit level.

In the management accounting system there are three methods for calculating the breakeven point: a mathematical method (equation method), contribution margin method (gross profit method), graphical method.

To calculate the breakeven point, the following formulas are used:

$$
\text { Profit }=\text { Sales revenue }- \text { Variable costs }- \text { Fixed costs }
$$

or

$$
\text { Profit }=\text { Unit price } \times X-\text { Variable costs per unit } \times X-\text { Fixed costs }
$$

Then, you should use the following equation:

$$
\mathrm{X} \times(\text { Unit price - Variable costs per unit }) \text { - Total fixed costs }=0
$$

In brackets we have contribution margin per unit. Finally, to calculate the breakeven point you should divide the total fixed costs by the contribution margin per unit:

$$
\text { Breakeven point }=\text { Total fixed costs }
$$

contribution margin per unit

Contribution margin method (gross profit method) is an alternative method and is calculated with the same formula.

Using the data in Table 2, we will calculate the break-even point for milk production and sale of young cattle.

The volume of milk sales at the break-even point is defined as follows

$1764330 \div 11.43=154.359$ bottles, or

$154.559 \times 30.07=4641575.13$ roubles.

The volume of sales of young calves at the break-even point is calculated as follows

$81690 \div 10.69=7641 \mathrm{~kg}$, or

$7641 \times 169.87=1297976.67$ roubles.

For making long-term management decisions, one can calculate the contribution margin ratio, i. e. the proportion of contribution margin and sales proceeds. The contribution margin ratio is calculated by dividing contribution margin per unit by sales proceeds and multiplying by $100 \%$.

Contribution margin per bottle of milk and per $\mathrm{kg}$ of young cattle is 11.43 roubles and 10.69 roubles, accordingly. Sales proceeds per bottle of milk is 30.47 roubles and per kg of young cattle is 169.87 roubles. Consequently, contribution margin ratio is $37.52 \%$ for milk and $6.30 \%$ for young cattle. This means that contribution margin per every 100 roubles is 37.52 roubles and 6.30 roubles, accordingly.

Thus, you can determine the amount of desired contribution margin by planning sales proceeds. For example, the company expects to get sales proceeds 7654380 roubles from the sale of milk and 2050000 roubles from the sale 
of young cattle. In this case, contribution margin will be 2910195 roubles and 313.650 roubles, accordingly.

To determine the operating profit (profit before taxes), it is necessary to subtract total fixed costs from contribution margin:

- Milk: 2910195 - 764,330 =1,145,865 roubles.

- Young cattle: $313,650-81,690=231,960$ roubles.

Thus, if you plan to make a total profit 7654380 roubles from the sale of milk and 2050000 roubles from the sale of young cattle, the profit will be 1145865 roubles and 231,960 roubles, accordingly.

It is also possible to determine the margin of safety which shows the amount by which sales of the company can decrease before it begins making losses. After necessary calculations, the margin of safety for milk is $39.36 \%$ and for young cattle-13.94\%. This means that the volume of sales can decrease by these percentages before the company begins making losses. If the company has a positive margin of safety, its profit is calculated as follows:

$$
\text { Profit }=\text { Margin of Safety } \times \text { Contribution margin per unit }
$$

Consequently, the profit from the sale of milk will be $39.36 \times 11.43=4.49$ roubles per bottle.

Thus, any change in the volume of sales leads to a greater change in profit. It is called the effect of operating leverage; degree of operating leverage shows the percentage change in profit.

The level of operating leverage for milk is: $(11.43 \div 4.49)=2.54$. Consequently, if next month's revenue from the sale of milk increases by $10 \%$, the profit will increase by $25.4 \%$.

At present, the determination of break-even point is of great importance. While using methods discussed above, the accountant can model various combinations of sales volume, costs and profits, choosing the most appropriate one. For making right management decisions on the basis of the contribution margin, the company should use a special document.

We have worked out a managerial document "The calculation of the contribution margin from agricultural products (cattle breeding, pig breeding, horse breeding, etc.)", which can be used to calculate the contribution margin for products of any agricultural enterprise.

When using methods in the framework of strategic and operational management accounting, agricultural enterprises can be recommended to fill in the form of accounting ledgers that we have worked out "Report on the costs and their results in agricultural enterprises while using direct costing and CVP-analysis" which is shown in Table 3.

Table 3. Report on the costs and their results in agricultural enterprises while using direct costing and CVP-analysis

\begin{tabular}{|c|c|c|c|c|c|c|c|}
\hline \multirow[t]{2}{*}{ Items } & \multirow{2}{*}{$\begin{array}{l}\text { Unit of } \\
\text { measur } \\
\text { ement }\end{array}$} & \multicolumn{2}{|c|}{ Planned value } & \multicolumn{2}{|c|}{ Current value } & \multicolumn{2}{|c|}{ Last year' s } \\
\hline & & $\begin{array}{l}\text { Amount } \\
\text { (weight, } \\
\text { volume) }\end{array}$ & Cost & $\begin{array}{l}\text { Amount } \\
\text { (weight, } \\
\text { volume) }\end{array}$ & Cost & $\begin{array}{l}\text { amount } \\
\text { (weight, } \\
\text { volume) }\end{array}$ & cost \\
\hline 1 & 2 & 3 & 4 & 5 & 6 & 7 & 8 \\
\hline \multicolumn{8}{|l|}{ 1. Output } \\
\hline \multicolumn{8}{|l|}{ 2. Variable costs, thousand roubles: } \\
\hline \multicolumn{8}{|l|}{ - Labour cost; } \\
\hline \multicolumn{8}{|l|}{ - Biologies, fertilizers; } \\
\hline \multicolumn{8}{|l|}{ - Zootechnical and veterinary care; } \\
\hline \multicolumn{8}{|l|}{ - Seeds, planting material; } \\
\hline \multicolumn{8}{|l|}{ - Feed; } \\
\hline \multicolumn{8}{|l|}{ - Raw materials and supplies; } \\
\hline \multicolumn{8}{|l|}{ - Heat supply; } \\
\hline - Electric power supply; & & & & & & & \\
\hline
\end{tabular}


- Packing;

- Other materials;

- Tractor fleet services;

- Other services.

Total variable costs, thousand roubles

3. Fixed costs, thousand roubles:

- Manufacturing costs;

- Overheads;

- Selling costs

Total fixed costs, thousand roubles

4. Total overall costs per month, thousand roubles

5. Total overall costs per year, thousand roubles

6. Unit price

7. Sales proceeds, thousand roubles

8. Total marginal revenue per month, thousand roubles

9. Total marginal revenue per year, thousand roubles

10. Operating profit, thousand roubles

When filling in the form of accounting ledgers, agricultural enterprises should define the key indicators which are determined in the centers of responsibility, the main ones are costs and profits. The source of data for internal reporting forms on the costs and profits are: operating report, consolidated personal account, analytical accounting report and other accounting records (Ruzhova, 2009). Agricultural enterprises should work out their own document structure. They create all the components that make up the document according to the technological peculiarities of production and agricultural processing, raw materials, conditions of sales and others.

In addition to Direct costing, in most Western countries Standard Cost is used to calculate the cost of goods (services) taking into account standards and variances in order to improve the efficiency of operational management and control.

This system is mainly aimed at controlling the use of the direct production costs and overheads. The advantage of Standard Cost is the possibility to define the amount of the expected total costs, calculate costs of goods or services, set properly the price and make an accounting report on expected profits. It is important to emphasize that Standard Cost allows to generate information on variances from standards, as well as their causes. It should be noted that the variances are not included in the cost of goods (services); the manufactured goods (services) have standard production cost. Thus, standard setting helps manage costs efficiently taking into account variances and avoid large fluctuations in the value of profits over different accounting periods; calculation of the actual production cost shows the real value of profit.

In international practice Standard Cost system is not regulated by any act, consequently, it has no single methodology for establishing standards and designing forms of accounting ledgers, it leads to the use of different standards (basic, current, ideal, forward-looking), even within a single enterprise.

In today's market conditions, the use of Standard Cost would allow agricultural enterprises to set objectively the price of agricultural products and, therefore, the monopoly of the processing enterprises could not affect the formation of prices of crop and livestock products.

When using standards it is recommended to use quantitative standards that will measure consumption of 
materials in real terms (biological products, milk, feed, oil and other raw materials), labor costs, heat supply and electric power supply costs. Then, these quantitative standards should be multiplied by the coefficients in terms of money; as a result, standard costs will be defined.

Due to the fact that overheads of agricultural enterprises cover various costs (maintenance of their own production, outsourced services, management costs etc.), it is recommended to represent standards of overhead in terms of money without quantitative standards.

For the calculation of standard costs of agricultural products standard direct costs and overheads should be summed; variances are defined as in Table 4.

Table 4. The procedure for calculating the variances from standard costs

\begin{tabular}{|c|c|c|}
\hline No. & Types of variances & The procedure for calculating variances \\
\hline \multicolumn{3}{|c|}{ Material costs } \\
\hline 1 & $\begin{array}{l}\text { Material } \\
\text { variance }\end{array}$ & (Standard price per unit-Actual price per unit) x Actual quantity \\
\hline 2 & $\begin{array}{l}\text { Material quantity } \\
\text { Variance }\end{array}$ & (Standard quantity - Actual quantity) x Standard price per unit \\
\hline 3 & $\begin{array}{l}\text { Total material } \\
\text { variance }\end{array}$ & (Standard costs per unit-Actual costs per unit) x Actual quantity \\
\hline \multicolumn{3}{|c|}{ Labour costs } \\
\hline 1 & $\begin{array}{l}\text { labour } \\
\text { variance }\end{array}$ & (Standard rate-Actual rate) x Actual hours worked \\
\hline 2 & $\begin{array}{l}\text { Labour Efficiency } \\
\text { Variance }\end{array}$ & (Actual hours - Standard hours) $\mathrm{x}$ Standard rate \\
\hline 3 & $\begin{array}{l}\text { Total labour } \\
\text { variance }\end{array}$ & (Standard labor costs per unit_-Actual labor costs per unit) x Actual quantity \\
\hline \multicolumn{3}{|c|}{ Overhead Costs } \\
\hline 1 & $\begin{array}{l}\text { Overhead } \\
\text { Variance }\end{array}$ & $\begin{array}{l}\text { (Standard overheads per unit-Actual overheads per unit) x Actual quantity of } \\
\text { produced goods }\end{array}$ \\
\hline
\end{tabular}

Thus, the most important point in Standard Cost is operational control of variances from standards. The use of this system will be conditional if agricultural enterprises don't control variances, as a result appropriate effect will not be achieved.

It should be noted that in practice it is quite difficult to develop standards according to the process card, as standards can't be applied to all production costs. However, despite it management uses Standard Cost as a powerful tool for monitoring and control of production costs, business process management, planning production program and making cost-effective decisions.

\section{Conclusion}

It is important to use methods for cost management as they are essential for making right management decisions. For example, direct costing method can be equally used with the traditional total cost accounting in the performance of agricultural enterprises. This information is necessary for the enterprise cost accounting and provides all important financial data to make management effective. CVP-analysis is used for planning profit performance and making short-term management decisions. It gives an opportunity to determine the right balance between variable and fixed costs, price and volume of manufactured products (services). Presented form of accounting ledgers has essential value for information and control management. It allows to organize operational control over the safety of accounting documents and provides cost information base that management needs to control current operations.

Thus, in an unstable financial situation well-chosen methods and strategic and operational management accounting will allow to:

- Manage the process costs and sales profitability competently and efficiently; 
- Make the company stronger in the market and improve the efficiency of business and financial activities;

- Assess correctly the contribution of each responsibility center to the covering common fixed costs and achieving the desired profit level;

- Justify ways of optimization of price composition and structure, improve the transparency of pricing policy for consumers of agricultural products and relevant regulatory authorities;

- Provide a management system with accounting and analytical information over a certain period of time;

- Control cost variances and avoid large fluctuations in the value of profits over different periods;

- Make informed management decisions based on optimal methods and strategic and operational management accounting to control certain operations for improving the efficiency of agricultural production.

\section{References}

Ailbright, T., \& Lam, M. (2006). Managerial Accounting Continuous Improvement Initiatives Text. $A$ Retrospective and Framework Journal of Managerial Issues, XVIII(2), 157-174.

Drury, K. (1998). Introduction to management and production accounting. Moscow: Audit.

Horngren, C., \& Foster, D. S. (2007). Managerial Accounting (Revised). St. Petersburg: Piter.

Kaspina, R.. G., \& Plotnikova, L. A. (2014). Accounting of external economic activity of Russian companies: Experience and difficulties. Life Science Journal, 11(11), 108-111.

Pizengolts, M. Z. (2002). Accounting in agriculture (Revised). Moscow: Finance and Statistics.

Ryzhova, L. I. (2009). The development of analytical cost accounting in horse breeding (Ph. D. thesis). Yoshkar-Ola: Mari State Technical University.

Ryzhova, L. I., \& Nikolaeva, L. V. (2014). Information and analytical support of cost management in horse breeding (Monograph). Yoshkar-Ola: Mari State University.

Ryzhova, L. I. (2014). The development and application features of internal regulatory registers to control and management in agricultural enterprises. Economics and Entrepreneurship, 11.

\section{Copyrights}

Copyright for this article is retained by the author(s), with first publication rights granted to the journal.

This is an open-access article distributed under the terms and conditions of the Creative Commons Attribution license (http://creativecommons.org/licenses/by/3.0/). 